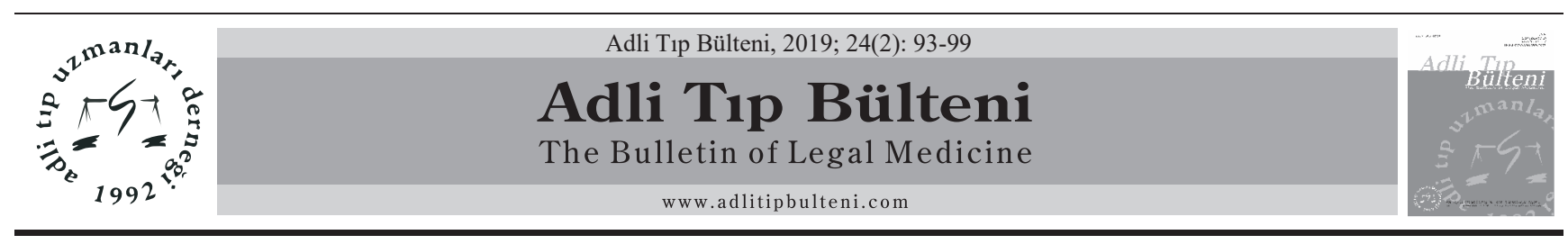

ARAȘTIRMA / RESEARCH ARTICLE

\title{
Sık Hastane Başvurusu Ev İçi Şiddetin Habercisi mi?
}

\section{Are the Recurrent Hospital Applications Inform About Domestic Violence?}

\author{
Yasemin Balc1, Gülsüm Kadı, Ümit Ünüvar Göçeoğlu*, Leman İnanç
}

\begin{abstract}
$\ddot{O} \mathbf{z}$
Amaç: Eş şiddeti toplumun her kesiminde değişik oranlarda görülmektedir ve orta-uzun vadede çok farklı sağlık sorunlarına neden olabilmektedir. Bu çalışmada, Adli Tıp Polikliniğine eşinden/partnerinden şiddet görme nedeniyle başvuran olguların son bir yıl içindeki hastane başvurularını değerlendirerek; şiddet mağdurlarının sağlık sorunlarını ortaya koymak ve şiddet ile ilişkisini belirlemek amaçlanmıştır.

Gereç ve Yöntem: 01 Haziran 2014-31 Mayıs 2017 tarihleri arasında Muğla Sttkı Koçman Üniversitesi Eğitim ve Araştırma Hastanesi Adli Tip Polikliniğine eş/partner şiddeti nedeniyle başvuran olguların demografik verileri yanı sıra, hastanemiz hasta kayıt sisteminden; her bir olgunun adli tıp polikliniğine başvurusundan önceki son bir yılda diğer poliklinik/klinik başvuruları geriye doğru incelenmiştir.

Bulgular: Belirtilen tarihlerde polikliniğimize başvuran toplam 3966 olgu arasından 198 olgu (\%5) eşi tarafından fiziksel şiddete maruz kalmıştı. Olguların 177'si (\%89.4) kadın, 21'i (\%10.6) erkekti. Yaş ortalaması $35.2 \pm 10.5$ (aralık 17-76) olup, en fazla olgu \%37.4 oranıyla 30-39 yaş grubundaydı. Rapor talep eden birim 115 olgu ile en fazla savcılık adına polis merkezleri idi. Olguların son bir yıl içinde hastanemizin değişik birimlerine başvuru sayısının ortalaması $7.5 \pm 8.5$ bulundu.

Olguların yıllık başvurusunda; tek bir poliklinikten 10 farklı polikliniğe kadar farklı başvuruları olabildiği, 1 ile 10 farklı semptom/yakınma ile başvurdukları tespit edildi. Yakınma ve semptomların en sık kas iskelet sistemi, gastrointestinal sistem ve psikiyatrik yakınma ve semptomlar olduğu görüldü. 39 yaş ve altındaki genç grubun başvuru sayısının istatistiksel olarak daha fazla olduğu görüldü.

Sonuç: Eş şiddetine maruz kalanların büyük çoğunluğunu kadınlar oluşturmaktadır. Şiddet mağdurlarının psikosomatik semptom ve yakınmalarla yıllık hastane başvuruları 10'un üzerinde olabilmektedir. 39 yaş ve altı olguların görece fazlalığı; şiddetin bedenselleştirilerek ifade edilmesi şeklinde yorumlanabilir. Kadınların şiddetin sonuçlarını bedenselleştirmeleri/somatize etmeleri bir yardım çığlığı olarak değerlendirilmeli, adli tıp ve psikiyatri uzmanlarının bu yönde farkındalığı arttırılmalı, bilgi ve beceri kazanmaları sağlanmalıdır. Çalışma verileri ileriye dönük önleyici öneriler geliştirilmesi açısından yararlı olacaktır.
\end{abstract}

Anahtar Kelimeler: Ev İçi Şiddet; Eş Şiddeti; Adli Tıp; Bedenselleştirme; Somatizasyon.

\section{Abstract}

Objective: The intimate partner violence is observed in all segments of society with different proportions. It can cause many different health problems in the medium-long term. In this study, we evaluated the hospital admissions in the last year in cases who were admitted to the Forensic Medicine Outpatient Clinic due to violence from his/her spouse/partner; to determine the health problems of the victims of violence and their relationship with violence.

Materials and Methods: The demographic data of the patients who applied to Muğla Sitkı Koçman University Education and Research Hospital Forensic Medicine Clinic due to the his/her spouse/partner violence between 01 June 2014 and 31 May 2017 were examined. In addition, other polyclinic/clinical applications were reviewed retrospectively in the last one year before the admission to the forensic medicine outpatient clinic.

Results: Among the total 3966 cases admitted to our outpatient clinic, 198 cases $(5 \%)$ were exposed to physical violence by their spouses. 177 (89.4\%) of the cases were female and $21(10.6 \%)$ were male. The mean age was $35.2 \pm 10.5$ (range 17-76) and the highest rate was in the 30-39 age group with $37.4 \%$. The highest number of requests for reports was from the police headquarters on behalf of the public prosecutor with 115 cases. The mean number of applications to different units was $7.5 \pm 8.5$ in the last year.

One-year application of cases; from one polyclinic to 10 different outpatient clinics, with 1 to 10 different symptoms/complaints. The most common complaints and symptoms related with musculoskeletal, gastrointestinal and psychiatric disorders. It was seen that the number of applications of the young group 39 years or younger were statistically higher.

Conclusion: The majority of victims who are subjected to spousal violence are women. Victims of violence may have more than 10 visits to the hospital within a year with psychosomatic symptoms and complaints. Relative excess of cases 39 years and younger; can be interpreted as somatic expression of violence. Somatization of the consequences of violence should be considered as a cry for help and the awareness of forensic medicine and psychiatry specialists should be increased. It should be ensured that they gain knowledge and skills in this subject. Recent study will be useful for developing future preventive recommendations.

Keywords: Domestic Violence; Intimate Partner Violence; Forensic Medicine; Alexithymia; Somatization.
DOI: 10.17986/blm.2019250195

Yasemin Balcı: Prof. Dr., Muğla Sitkı Koçman Üniversitesi Tıp Fakültesi Adli Tıp Anabilim Dalı, Muğla Eposta: yaseminbalc1@mu.edu.tr ORCID iD: https://orcid.org/0000-00025995-9924

Gülsüm Kadı: Arş. Gör. Dr., Muğla Sttkı Koçman Üniversitesi Tıp Fakültesi Adli Tıp Anabilim Dalı, Muğla Eposta: gulsumkadi@gmail.com ORCID iD: https://orcid.org/ ORCID: 0000-0003-3763-1407

Ümit Ünüvar Göçeoğlu: Doç. Dr., Muğla Sıtkı Koçman Üniversitesi Tıp Fakültesi Adli Tıp Anabilim Dalı, Muğla Eposta: umitunuvar@mu.edu.tr ORCID iD: https://orcid.org/0000-00031646-7492

Leman İnanç: Dr. Öğr. Üyesi: Muğla Sitkı Koçman Üniversitesi Tıp Fakültesi, Ruh Sağlığı ve Hastalıkları Anabilim Dalı, Muğla

Eposta: leman.inanc@gmail.com ORCID iD: https://orcid.org/0000-00022939-3464

Bildirimler/ Acknowledgement: Yazarlar bu makale ile ilgili herhangi bir çıkar çatışması bildirmemiş̧lerdir. Yazarlar bu makale ile ilgili herhangi bir finansal destek bildirmemişlerdir. The authors declare that they have no conflict of interests regarding content of this article.

The Authors report no financial support regarding content of this article.

Geliş: 11.01 .2019

Düzeltme: 08.02.2019

Kabul: 26.02.2019

p-ISSN: 1300-865X

e-ISSN: $2149-4533$ 


\section{Giriş}

Aile içi şiddet, ülkemizde ve dünyada önemli bir toplumsal sorun olarak pek çok sosyal, sağlık ve ekonomik zararlara yol açmaktadır. Aile içi şiddetin en sık rastlanan formlarından birisi eş şiddetidir. Eş şiddeti, çoğunlukla aile içinde eşe ya da sevgili/partner ilişkisinde erkeğin kadına uyguladığı şiddet şeklinde karşımıza çıkmakla birlikte, erkekler de eş/partner şiddetine maruz kalabilmektedir. Eş şiddeti fiziksel-duygusal-cinsel ve ekonomik şiddet şeklinde farklı biçimlerde ya da bunların kombinasyonları şeklinde olabilmektedir. Şiddet kurbanları için, yaşanılan eş şiddetini kabullenmek ve ifade etmek her zaman kolay olmamaktadır (1). Eş şiddeti yaşayanların önemli bir kısmı şiddete ilk maruz kaldığında yarg1 birimlerine başvurmamaktadır. Diğer yandan eş şiddeti mağdurlarının psikosomatik yakınmalarla sağlık birimlerine başvurdukları bilinmektedir. Tüm dünyada ve farklı kültürel gruplar arasında toplumsal sorunların ve duygusal sıkıntının en yaygın bireysel ifadelerinden birisi bedensel belirtilerle sağlık kuruluşlarına başvurmaktır. Temelde ruhsal ve sosyal alanda yaşanan sorunlara ilişkin yardım arama davranışı olarak tanımlayabileceğimiz somatoform bozukluklar "bedenselleştirme" olarak adlandırılan bu durumun tipik bir yansımasıdır (1-3).

Bedenselleştirme ya da somatizasyon, stres karşısında fiziksel yakınmaların organik nedenlerle açıklanamadığı durumlarda kullanılan bir terimdir. Somatizasyon kavramı, ruhsal bedensel sınırda kalan, açıklanması güç yakınmaları kapsamaktadır. Bir çalışmada birinci basamakta bedenselleştirmenin \%22 oranında saptandığ dirilmiştir (3).

Bedenselleştirmeye dair ortaya atılan atıf kuramına göre; kişi bazı bedensel belirtileri çevresel faktörlerle açıklayarak normalleştirmekte ya da psikolojik nedenlerle ilişkilendirme yoluyla ruhsallaştırmakta ya da fiziksel bir hastalığa bağlayarak bedenselleştirmektedir (4).

Hasta bedensel yakınmaları aracılığı ile ifade edilmesi güç duygularını ifade edebilmek, bu duyguları aktarabilmek, anlaşılmak, onaylanmak, acı verici olaylardan uzak durmak, kişiler arası iletişimi sürdürmek ve ilgi görmek için bedenselleştirmeyi kullanabilir. Kişisel özellikler, bilişsel özellikler, duygularını ifade edebilme yetisi bedenselleştirmeye katkıda bulunabilir (5).

Travma sonrası oluşan stres tepkisi bazı beden belirtileri, bedenle aşırı uğraş, uyku ve dikkat sorunları ve geçici duygudurum bozuklukları ortaya çıkmasına yol açabilir. Akut stres tepkileri geçici bedensel belirtilere neden olabilir (5).

Bedenselleştiren hastalarda duygularını tanıyamama ve ifade edememe olarak tanımlanan aleksitimi s1klıkla görülür. Aleksitimik bireyler duygu ve düşünce arasında ilişki kurmakta zorlanırlar. Bu duygular için söz yokluğu olarak da tanımlanabilir. Hastalar bedensel yakınmalarını tüm ayrıntıları ile tanımlarken duygulardan söz etmezler. $\mathrm{Bu}$ kişilerin bedensel yakınmalar nedeniyle çok sayıda başvurusu olabilir (6).

Eş şiddeti olgularını saptayabilmek ve doğru bir şekilde yönetebilmek, sağlık çalışanlarının temel işlevlerinden ve mesleki sorumluluklarından birisidir. Bu açıdan, sağlık çalışanlarının eş şiddetini ve aile içinde şiddet dinamiklerini fark edebilmesi yanı sıra şiddetin bedenselleştirilerek ifade edilmesi durumunu da fark edebilmeleri önemlidir. Birden fazla ve farklı hastane başvuruları, birden fazla ve farklı yakınma ve semptomlar belki de şiddet karşısında bedenin verdiği bir yardım çığlığ 1 olabilir.

Şiddet mağduriyeti ile fiziksel ve ruhsal sağlık yakınmaları arasındaki bir ilişki olduğunu gösteren çalışmalar; bunu geniş çaplı çalışmalar, anketler ve klinik görüşmelerden elde edilen verilere dayandirmaktadır (7-17). Bu çalışmada, eşinden/partnerinden şiddet görerek şikayetçi olan ve adli nitelikli rapor düzenlenmesi için adli tıp polikliniğine başvuran olguların, gönderilmeye konu şiddet olayı tarihinden geriye dönük bir yıl içindeki tüm hastane başvuruları incelenmiştir. Şiddet ile kişilerin fiziksel-ruhsal sağlık sorunları arasındaki ilişkiyi tartışmak ve ileriye dönük geniş kapsamlı çalışmalar için bir veri tabanı oluşturabilmek amaçlanmıştır.

\section{Gereç ve Yöntem}

01 Haziran 2014-31 Mayıs 2017 tarihleri arasında Muğla Sıtkı Koçman Üniversitesi (MSKÜ) Eğitim ve Araştırma Hastanesi Adli Tıp Polikliniğine eşinden/partnerinden şiddet görme sonucu adli rapor düzenlenmesi talebiyle başvuran 198 olgu çalışmaya dahil edilmiştir. Olguların demografik verileri yanı sıra, hastanemiz hasta kayıt sisteminden; her bir olgunun adli tıp polikliniğine başvurusundan önceki bir yıl içinde hastaneye yaptığ 1 farklı başvuruları geriye doğru incelenmiştir. Kişilerin toplam başvuru sıklığı, hangi poliklinik/kliniklere başvurduğu, yakınmaları ve semptomları değerlendirilmiştir. İstatistiksel değerlendirme açısından başvuru sayıları 12 ve altı (ayda bir ve daha az), 13 ve üzeri (ayda birden fazla) olarak, yaş grupları da 39 yaş ve altı, 40 yaş ve üzeri olarak gruplandırılmıştır.

Mağdurların başvuruya konu yakınma/semptomları; Psikosomatik olduğu düşünülen yakınma ve semptomlar (kas-iskelet sistemi, gastrointestinal semptomlar, psikiyatrik semptomlar, solunum-dolaşım sistemi semptomları, nörolojik semptomlar, kadın hastalıkları ile ilgili semptomlar, deri semptomları ve üriner sistem semptomları) ile psikosomatik olmayan başvurular (organik sağlık 
sorunları, yaralanma ve adli nitelikli başvurular) olarak iki ayrı grupta değerlendirilmiş, iki grup arasında istatistiksel karşılaştırma yapılmıştır.

Veriler SPSS versiyon 22 program kullanılarak değerlendirilmiş, veri analizinde, yüzde, oran ve ki-kare istatistikleri kullanılmış, $\mathrm{p}<0.05$ anlamlı farklılığın göstergesi olarak kabul edilmiş ve veriler tablolar halinde sunulmuştur.

Çalışma, Muğla Sıtkı Koçman Üniversitesi İnsan Araştırmaları Etik Kurulunun 17.07.2018 onay tarihli kararı ile yapılmıştır.

\section{Bulgular}

01 Haziran 2014-31 Mayıs 2017 tarihleri arasındaki 3 yıllık periyotta MSKÜ Eğitim ve Araştırma Hastanesi Adli Tıp Polikliniğinde düzenlenen toplam 3966 rapor içinden 198 raporun (\%5) eş/partner şiddeti nedeniyle düzenlendiği görülmüştür. Düzenlenen her 20 rapordan biri eş/partner şiddeti nedeniyle düzenlenmiştir.

Olguların \%89.4'ü (n:177) kadın, \%10.6'sı (n:21) erkek mağdurlardır. Yaş ortalaması $35.2 \pm 10.5$ olup en genç olgu 17, en yaşlı olgu 76 yaşındadır. En fazla olgu 30-39 yaş grubundadır (\%37.4). Olguların yaş aralıklarına göre dağılımı Tablo 1'de sunulmuştur.

Tablo 1. Olguların yaş aralıklarına göre dağılımı

\begin{tabular}{|l|c|c|}
\hline Yaş aralıkları & $\mathbf{n}$ & \% \\
\hline 19 ve altı & 3 & 1.5 \\
\hline $20-29$ & 59 & 29.8 \\
\hline $30-39$ & 74 & 37.4 \\
\hline $40-49$ & 44 & 22.2 \\
\hline 50 ve üstü & 18 & 9.1 \\
\hline Toplam & $\mathbf{1 9 8}$ & $\mathbf{1 0 0 . 0}$ \\
\hline
\end{tabular}

Başvuruya konu şiddet olayının yaşandığı ay ve mevsimlere göre dağılım Tablo 2'de verilmiştir. Şiddet olay1nın en fazla sıklıkla (\%64) ev ortamında daha fazla zaman geçirilen kış mevsiminde gerçekleştiği görülmektedir.

Eş/partner şiddeti olguları için en fazla rapor talebi Savcıllklar adına polis merkezleri tarafindan yapılmaktadır (\%58). Rapor talep eden birimlerin dağılımına bakıldığında; en sık \%58 (n:115) oranıyla Savcılık adına Polis merkezlerinden olgu gönderildiği görülmüştür. Bunu jandarma merkezleri \%25.3 (n:50), yargı birimleri \% 16.7 (n:33) oranılla izlemektedir.

Rapor taleplerinin istendiği ilçelerin dağılımına bakıldığında; en fazla rapor talebinin Muğla merkez ilçeden (\%61) olduğu görülmüştür, bunu sırasıyla Yatağan (\%15.7), Ula (\%8.1) ve Köyceğiz (\%5.6) ilçeleri izlemiştir.
Tablo 2. Başvuruya konu şiddet olayının yaşandığ 1 ay ve mevsimlere göre dağılımı

\begin{tabular}{|c|c|c|c|c|c|}
\hline Aylar & n & $\%$ & Mevsimler & $\mathbf{n}$ & $\%$ \\
\hline Aralık & 21 & 10.5 & \multirow{3}{*}{$\mathrm{K}_{1 S ̧}$} & \multirow{3}{*}{64} & \multirow{3}{*}{32.1} \\
\hline Ocak & 20 & 10.1 & & & \\
\hline Şubat & 23 & 11.5 & & & \\
\hline Mart & 19 & 9.6 & \multirow{3}{*}{ İlkbahar } & \multirow{3}{*}{51} & \multirow{3}{*}{25.8} \\
\hline Nisan & 17 & 8.6 & & & \\
\hline May1s & 15 & 7.6 & & & \\
\hline Haziran & 12 & 6.1 & \multirow{3}{*}{ Yaz } & \multirow{3}{*}{45} & \multirow{3}{*}{22.8} \\
\hline Temmuz & 14 & 7.1 & & & \\
\hline Ağustos & 19 & 9.6 & & & \\
\hline Eylül & 12 & 6.1 & \multirow{3}{*}{ Sonbahar } & \multirow{3}{*}{38} & \multirow{3}{*}{19.3} \\
\hline Ekim & 11 & 5.6 & & & \\
\hline Kasım & 15 & 7.6 & & & \\
\hline Toplam & 198 & 100.0 & Toplam & 198 & 100.0 \\
\hline
\end{tabular}

Eş şiddetine maruz kalan kadınlardan 17'sinde, şiddet tarihinden önceki bir yıl içinde gebelik takibi yapıldığı anlaşılmıştır. Bu olgular şiddet sırasında gebe ya da yeni doğan bebekli olgulardır.

Eş/partner şiddeti nedeniyle rapor düzenlenen olguların adli rapor başvurusundan önceki bir yılda hastaneye kaç kez, hangi klinik/polikliniklere, hangi yakınma ve semptomlarla başvurdukları incelenmiştir.

Hastaneye başvuru sayısı: Olguların 28'inin (\%14.1) rapor talebine konu şiddet olayı dışında son bir yıl içinde herhangi bir hastane başvurusunun olmadığı görülmüştür. Tüm olgular son bir y1l içinde toplamda 1483 kez hastaneye başvurmuştur. Olguların son bir yıl içinde polikliniklere başvuru sayı ortalaması $7.5 \pm 8.5^{\prime}$ tir (minimum 0 , maksimum 46).

Tablo 3 ve 4 'te, başvuru sayılarının cinsiyete ve yaşa göre dağılımı görülmektedir.

Tablo 3. Cinsiyete göre başvuru sayılarının dağılımı.

\begin{tabular}{|l|c|c|c|}
\hline \multirow{2}{*}{$\begin{array}{l}\text { Başvuru } \\
\text { sayıs1 }\end{array}$} & \multicolumn{3}{|c|}{ Cinsiyet } \\
\cline { 2 - 4 } & Kadın n (\%) & Erkek n (\%) & Toplam n (\%) \\
\hline 12 ve altı & $144(81.4)$ & $15(71.4)$ & $159(80.3)$ \\
13 ve üzeri & $33(18.6)$ & $6(28.6)$ & $39(19.7)$ \\
Toplam & $\mathbf{1 7 7 ( 1 0 0 . 0 )}$ & $\mathbf{2 1 ( 1 0 0 . 0 )}$ & $\mathbf{1 9 8}(\mathbf{1 0 0 . 0 )}$ \\
\hline
\end{tabular}

$P=0.279$

Cinsiyete göre başvuru sayısında istatistiksel olarak anlamlı bir farklılık saptanmamıştır. 
Tablo 4. Yaş gruplarına göre başvuru sayılarının dağılımı.

\begin{tabular}{|l|c|c|c|}
\hline \multirow{2}{*}{$\begin{array}{l}\text { Başvuru } \\
\text { sayıs1 }\end{array}$} & \multicolumn{3}{|c|}{ Yaş Grubu } \\
\cline { 2 - 4 } 12 ve altı & $102(75.0)$ & $57(91.9)$ & $159(80.3)$ \\
\hline 13 ve üzeri & $34(25.0)$ & $5(8.1)$ & $39(19.79$ \\
\hline Toplam & $\mathbf{1 3 6}(\mathbf{1 0 0 . 0})$ & $\mathbf{6 2}(\mathbf{1 0 0 . 0})$ & $\mathbf{1 9 8}(\mathbf{1 0 0 . 0})$ \\
\hline$P=0.005$
\end{tabular}

Yaş grubuna göre başvuru sayısı değerlendirildiğinde, 39 yaş ve altındaki daha genç grupta başvuru sayısı istatistiksel olarak daha fazladır.

Başvuru yapılan birimler: Olguların adli rapor başvurusundan önceki bir yıl içinde değişik birimlere farklı sayıda başvuruları olmuştur; Öyle ki, olguların 45'i tek, 126's1 iki, 97'si 3, 76's1 4, 48'i 5, 30'u 6, 16's1 7, 11'i 8, 5'i 9, 1 'i de 10 farklı klinik/polikliniğe başvuru yapmıştır. Olguların son bir yıl içinde başvuru yaptıkları klinik/polikliniklerin dağılımı Tablo 5'de gösterilmiştir. Olguların en fazla başvuru yaptığı birimler; Acil Tıp (146/198; \% 73.7), Kadın Hastalıkları (54/198; \% 27.3), İç Hastalıklar1 (41/198; \%20.7), Kulak Burun Boğaz (35/198; \%17.7) ve Ruh Sağlığ 1 (32/198; \%16.2) poliklinikleri olmuştur.

Başvuru nedeni olan yakınma ve/veya semptomlar: Eş/partner şiddeti mağdurlarının başvurdukları klinik ya da polikliniklere 1 ile 10 farklı semptom ya da yakınma ile başvurdukları tespit edilmiştir.

Daha önce hastane başvurusu olmayan 28 kişi hariç tutulduğunda geri kalan olguların; 36'sı tek bir yakınma/

Tablo 5. Son bir yıl içinde eş/partner şiddeti dışında farklı polikliniklere başvuru yapan olguların dağılımı.

\begin{tabular}{|l|c|l|c|l|c|}
\hline Poliklinik & n (\%) & Poliklinik & n (\%) & Poliklinik & n (\%) \\
\hline Acil Tıp & $146(73.7)$ & Göğ̈̈s hastalıkları & $22(11.1)$ & Göğüs cerrahisi & $3(1.5)$ \\
\hline Kadın-doğum & $54(27.3)$ & Adli tıp & $19(9.6)$ & Ketem & $3(1.5)$ \\
\hline İç Hastalıkları & $41(20.7)$ & Kardiyoloji & $16(8.1)$ & Gastroenteroloji & $3(1.5)$ \\
\hline KBB & $35(17.7)$ & Fizik tedavi & $10(5.0)$ & Aile Hekimliği & $2(1.0)$ \\
\hline Ruh Sağlı̆̆1 & $32(16.2)$ & Üroloji & $9(4.5)$ & Radyoloji & $2(1.0)$ \\
\hline Beyin cerrahisi & $30(15.1)$ & Enfeksiyon & $8(4.0)$ & Romatoloji & $1(0.5)$ \\
\hline Genel Cerrahi & $29(14.6)$ & Nöroloji & $6(3.0)$ & Endokrin & $1(0.5)$ \\
\hline Cildiye & $29(14.6)$ & Plastik Cerrahi & $4(2.0)$ & Meme Cerrahisi & $1(0.5)$ \\
\hline Ortopedi & $25(12.6)$ & Kalp damar & & & \\
\hline Göz & $23(11.6)$ & & & \\
\hline
\end{tabular}

Tablo 6. Olguların cinsiyete göre başvuruya konu yakınma/semptomlarının dağılımı.

\begin{tabular}{|l|c|c|c|}
\hline Semptom grubu & Kadın (n:177) n (\%) & Erkek (n:21) n (\%) & Toplam (n:198) n (\%) \\
\hline Psikosomatik olarak değerlendirilemeyen & $\mathbf{2 1 8 ( 3 6 . 5 )}$ & $\mathbf{3 2}(\mathbf{7 2 . 7})$ & $\mathbf{2 5 0}(\mathbf{3 4 . 5 )}$ \\
\hline Organik să̆lık sorunları & $105(17.6)$ & $20(45.5)$ & $125(19.5)$ \\
\hline Yaralanma & $33(5.5)$ & $3(6.8)$ & $36(5.6)$ \\
\hline Adli tıbbi başvurular & $80(13.4)$ & $9(20.4)$ & $89(13.9)$ \\
\hline Psikosomatik olarak değerlendirilebilen & $\mathbf{3 8 0}(\mathbf{6 3 . 5})$ & $\mathbf{1 2}(\mathbf{2 7 . 3 )}$ & $\mathbf{3 9 2}(\mathbf{6 5 . 5 )}$ \\
\hline Kas-iskelet sistemi & $89(14.9)$ & - & $89(13.9)$ \\
\hline Gastrointestinal semptomlar & $63(10.5)$ & $5(11.4)$ & $68(10.6)$ \\
\hline Psikiyatrik semptomlar & $61(10.2)$ & - & $61(9.5)$ \\
\hline Solunum-dolaşım sistemi & $48(8.0)$ & $4(9.1)$ & $52(8.1)$ \\
\hline Nörolojik semptomlar & $45(7.5)$ & $1(2.3)$ & $46(7.1)$ \\
\hline Kadın hastalıkları & $35(5.9)$ & - & $35(5.4)$ \\
\hline Deri semptomları & $27(4.5)$ & - & $27(4.2)$ \\
\hline Üriner sistem semptomları & $12(2.0)$ & $2(4.5)$ & $14(2.2)$ \\
\hline Toplam & $\mathbf{5 9 8}(\mathbf{1 0 0 . 0}$ & $\mathbf{4 4}(\mathbf{1 0 0 . 0})$ & $\mathbf{6 4 2}(\mathbf{1 0 0 . 0})$ \\
\hline
\end{tabular}

*Ki-kare (Continuity Correction): 21.179, p:,000, test psikosomatik olarak değerlendirilemeyecek ve psikosomatik olarak değerlendirilebilecek şeklinde 2 grup arasında yapılmiştır. 
semptomla, 22'si iki farklı, 22'si 3 farklı, 15'i 4 farklı, 11'i 5 farklı, 13'ü 6 farklı, 15'i 7 farklı, 7'si 8 farklı, 5'i 9 farklı, 10’u 10 farklı semptom/yakınma ile değişik klinik/polikliniklere başvuruda bulunmuştur. Mağdurların cinsiyete göre başvuruya konu yakınma/semptomlarının dağılımı Tablo 6'da gösterilmiştir. Tüm olguların hastane başvurusuna neden olan yakınma ve/veya semptom say1s1 642 olup bunların \%93.1'i (n:598) kadınlara, \%6.9'u (n:44) erkeklere ait olup kadınlarda kişi başı ortalama yakınma sayısı 3.4 (598/177) iken erkeklerde bu oran 2.1 'dir (44/21). Kadınların yakınmalarının \%17.6'sı organik nedenler iken, erkeklerin yakınmalarının \%45.4'ü organik nedenlerdir.

Cinsiyet farkı gözetmeksizin, eş şiddetine uğrayan kişilerin hastaneye başvuru semptomlarının \% 61'i psikosomatik olarak değerlendirilebilecek nedenlerdir. Olguların başvuruya konu yakınma /semptomları arasında en fazla \%13.9 oraniyla kas iskelet sistemi olup bunu sirasıyla gastrointestinal sistem (\%10.6) ve psikiyatrik yakınma ve semptomların (\%9.5) izlediği saptanmıştır.

Kişilerin tıbbi kayıtları, tedavi yaklaşımı vb. değerlendirildiğinde, sağlık sorunu psikosomatik olarak değerlendirilemeyecek ve psikosomatik olarak değerlendirilebilecek durumlar açısından yapılan istatistiksel analiz sonucunda; kadınlarda psikosomatik olarak değerlendirilebilecek nedenlerle başvuru oranının erkeklere göre anlamlı derecede fazla olduğu saptanmıştır $(\mathrm{p}<0,000)$.

\section{Tartışma}

Muğla Sıtkı Koçman Üniversitesi Eğitim ve Araştırma Hastanesi Adli Tıp Polikliniğinde rapor düzenlenen olguların \%5'i eş/partner şiddeti nedeniyle başvuran olgulardır. Polikliniğimizde yılda 60-70 arası diğer bir deyişle haftada en az bir eş/partner şiddeti ile karşılaşılmaktadır. Ülkemizde kadına yönelik şiddetin yaygınlığına rağmen, şiddet gören her 10 kadından sadece 1 tanesi resmi bir kuruma başvurmakta, olguların çoğu gizli kalmaktadır. Kadınlar, korku, utanma, damgalanma endişesi, ekonomik-sosyal ihtiyaçlar, çocuklarının güvenliğini ve sağlığını koruma gereksinimi gibi nedenlerle şikayetçi olmaktan ve hatta yakınlarına bile anlatmaktan kaçınmaktadir $(18,19)$.

Eş/partner şiddeti nedeniyle rapor düzenlenen olguların \%89.4'ü (n:177) kadın, \%10.6'sı (n:21) erkek mağdurlardır, yaş ortalaması 35.2 olarak bulunmuştur. En fazla olgunun 30-39 yaş grubunda olduğu (\%37.4) görülmüştür (Tablo 1). Adli rapor için başvuru yaşı, yapılan diğer çalışmalarla benzer şekilde bulunmuştur (20, 21). Rapor düzenleme aşamasında şiddetin uzantıları ile de karşılaşılmaktadır; öyle ki olgularımızın 3'ü eski eşinden, 2'si eşi ile birlikte eşinin sevgilisinden, 2'si de eşi ile birlikte çocuk ya da eşin akrabasından şiddet gördüğünü ifade etmiştir.

Ev içi eş şiddeti, ev ortamında daha fazla zaman geçirilen kış mevsiminde gerçekleşmektedir (Tablo 2). Rapor talebi, en fazla savcılık adına polis merkezlerinden yapılmaktadır. Olguların üçte ikisi merkez ilçeden gelmiştir, bunun nedeninin Polikliniğimizin il merkezinde olmasına bağlanmıştır. Diğer ilçelerdeki eş/partner şiddeti olgularının önemli bir kısmının raporu bulundukları yerlerdeki diğer sağlık kuruluşlarından talep edilmektedir. Olguların önemli bir kısmının il içindeki Adli Tıp Şube Müdürlüğüne yönlendirildiği, önemli bir kısmının hiç adli tıp birimine yansımadığı, hiç hastaneye gitmeyen ya da hiç adli birimlere yansımayan pek çok olgu olduğu göz önüne alındığında, gerçek olgu sayısının veri tabanımızdaki olgu sayısından çok daha fazla olduğu dikkate alınmalıdır. Dolayısıyla eş şiddeti nedeniyle adli rapor düzenlenen olgular, eş şiddetinin gerçek sıklığını göstermemektedir.

Eş/partner şiddeti olgularının, şiddet dışındaki değişik sağlık sorunları ile son bir yıl içindeki hastane başvuruları incelendiğinde, şiddete uğrayan 198 kişinin toplamda 1483 kez hastane başvurusu olduğu, bir başka deyişle olguların son bir yıl içinde polikliniklere ortalama başvuru sayısının 7.5 olduğu görülmüştür. Cinsiyete göre başvuru sayısında istatistiksel olarak anlamlı bir farklılık saptanmaz iken (Tablo 3), 39 yaş ve altındaki daha genç grupta başvuru sayısı istatistiksel olarak daha fazladır (Tablo 4). Bu beklenenin tersi bir durum olup genç ve eş şiddeti mağdurlarının imdat çığlığı olabilir. Bu durum, 40 yaş ve üzerinde eş şiddeti kanıksanırken, 39 yaş ve altında şiddetin ifade edilmesindeki güçlüğün, psikosomatik nedenlerle sık hastane başvurusu olarak yansıdığını düşündürebilir.

Olguların hastanemiz dışındaki sağlık kuruluşlarına olan başvuruları değerlendirme kapsamında olmadığından, sağlık kuruluşlarına başvuru oranının daha yüksek olabileceği dikkate alınmalıdır. En sık başvuru yapılan bölümler, acil servis, kadın hastalıkları, iç hastalıkları, KBB ve ruh sağlığı birimleridir (Tablo 5). Psikiyatri polikliniğine başvuran ya da psikiyatri kliniğinde yatan kadın hastaların öz geçmişleri ayrıntılı incelendiğinde çoğunluğunun yaşamı boyunca en az bir tipte şiddete maruz kaldıkları araştırmalarda gösterilmiştir $(7,8)$. Kayahan ve ark.'1 (9); bir sağlık ocağı bölgesinde örneklenerek seçilen 15-49 yaş arası kadınlara uyguladıkları depresyon ölçekleri ile yaptıkları çalışmada, önceden depresyon öyküsü olan ve son bir yıl içinde evlilik sorunu yaşayan kadınlarda ölçek puanlarının daha yüksek olduğunu bulmuşlardır. Yapılan çalışmalarda, depresyonla aleksitimi (bedenselleştirme) arasında istatistiksel olarak anlamlı ilişki saptanmıştır (10). 
Olgularımızın başvuruya konu yakınma ve semptomları en s1k kas iskelet sistemi, gastrointestinal sistem ve psikiyatrik yakınma ve semptomlardır (Tablo 6). Psikosomatik olduğu düşünülen nedenlerle başvurma oranı, kadınlarda erkeklere göre daha fazladır. Cinsiyet farkı gözetmeksizin, eş şiddetine uğrayan kişilerin hastaneye başvuru semptomlarının \%61'i psikosomatik olduğu düşünülen nedenlerdir (Tablo 7).

Özer ve ark.’1 (11) tarafından, ağrı şikâyetiyle fizik tedavi polikliniğine başvurup fibromiyalji tanısı konulan hastalarda aile içi fiziksel şiddetin ağrı şiddeti, depresyon ve anksiyete belirtileri ile ilişkili olduğu bulunmuş olup fibromiyalji hastalarının tedavi ve izlem sürecinde aile içi şiddetin araştırılması ve eşlik eden anksiyete ve depresyon belirtilerinin değerlendirilmesi gerektiğine vurgu yapılmıştır.

Çilli ve ark.'nın (12), çalışan kadınlar ve ev kadınları üzerinde yapılan karşılaştırmalı çalışmasında, ev kadınlarında anksiyete, fobi, paranoid ve somatizasyon alt ölçek puanları ve global şiddet indeks ortalamasının çalışan kadınlara göre anlamlı derecede daha yüksek olduğu bulunmuştur. Coker ve ark.'nın (13) partner şiddeti mağduru geniş bir popülasyonda yapılan çalışmasında, psikolojik şiddette daha fazla olmak üzere fiziksel ve psikolojik şiddet mağduriyeti ile depresyon belirtileri, madde kullanımı, kronik fiziksel ve mental hastalıklar ve yaralanmalar arasında ilişki olduğu saptanmıştır. Coker ve ark.'nın (14) yaptıkları başka bir çalışmada, aile hekimliği kliniğine değişik sağlık sorunları ile başvuran kadın hastaların partner şiddetine maruziyetini sorgulamışlar, çalışmayı engelleyen bir engellilik, artrit, kronik ağrı, migren ve diğer baş ağrıları, kekeleme, cinsel yolla bulaşan enfeksiyonlar, kronik pelvik ağrı, mide ülserleri, spastik kolon, hazımsızlık, ishal veya kabızlık gibi olumsuz sağlık sonuçlarının büyük çoğunluğu ile psikolojik şiddette daha fazla olmak üzere fiziksel ve psikolojik şiddet yaşama arasında güçlü bir şekilde ilişki olduğunu bildirmişlerdir.

Doğanavşargil ve Vahip (15), klinik görüşme ile saptanan aile içi şiddet oranının anketle belirlenen orana göre istatistiksel olarak anlamlı derecede yüksek olduğunu, dolayısıyla aile içi şiddetin en iyi klinik görüşme ile saptanabileceğini ve psikiyatrik görüşme ortamının bunun için en uygun ortam olduğunu belirtmişlerdir.

Benzer şekilde Dünya Sağlık Örgütünün çoklu ülke çalışmasından 10 ülke verilerinin değerlendirildiği çalışmada yaklaşık 24 bin kadınla yapılan anket sonuçlarından, yaşadığı sürede eş/partner şiddeti gören kadınların fiziksel ve ruhsal sağlık bulgularının şiddet görmeyenlere göre daha olumsuz olduğu ifade edilmiştir (16). Amerika Birleşik Devletleri'nde "the Centers for Disease Control and Prevention" sponsorluğunda telefonla 70 bin kişiye ulaşılan ankette de benzer sonuçlar elde edilmiştir (17).

Özyurt ve Deveci (22), bir sağlık ocağı bölgesinde 1549 yaşları arasındaki evli kadınlarda depresif belirti yaygınlığı ve depresyon puanları ile aile içi şiddet arasındaki ilişkiyi anket ve ölçekler aracılığı ile araştırmış; lojistik regresyon analizi sonucunda, kronik hastalık varlığı ve aile içi şiddet öyküsü ile depresyon arasında pozitif bir ilişki olduğunu göstermişlerdir. Kadınların \%32.9'unun evlilikleri süresince aile içi şiddet öyküsü verdiği, aile içi şiddete maruz kaldığını ifade eden kadınların \%32.4'ünde depresif belirtiler varken şiddet görmediğini ifade edenlerde bu oranın \%6 olduğunu bildirmişlerdir.

Şiddet gören kadınların, yorgunluk, uyku bozukluğu, kâbus görme, sersemlik, çarpıntı, depresif semptomlar, travma sonrası stres bozukluğu, anksiyete ve intihar girişimleri gibi psikosomatik yakınmalar, gastrointestinal şikayetler, nefes darlığı, adet düzensizliği, baş, göğüs, karın ağrısı gibi kronik yakınma ve belirtilerle sağlık kuruluşlarına başvurabildikleri ve bu durumun, aile içi şiddetin bireysel yansımaları olduğu bilinmektedir (19, 23, 24). Bu nedenle, hekimin şiddet olasılığını akılda tutmaS1, tanı için anahtar rol oynamaktadır. Hekimler kadınları muayene ederken, eşinin/partnerinin bulunmadığı bir ortamda ve yüz yüze; net bir şekilde şiddet görüp görmediğini, incinip incinmediğini, şimdiki ya da önceki evliliği/ ilişkisinde kendisini güvende hissedip hissetmediğini sorgulamalıdir (19).

Bedenselleştirmeye vurgu yapan, fiziksel ve ruhsal sağlık sorunları ile eş/partner şiddeti arasındaki ilişkiyi gösteren geniş çaplı çalışmaların yüz yüze ya da telefonla anket şeklinde yapıldığı ya da psikiyatri ve aile hekimliği birimlerine şiddet dışı nedenle başvuranlara yapılan klinik görüşme ile şiddet mağduriyetinin sorgulandığı anlaş1lmıştır (7-17).

$\mathrm{Bu}$ çalışmada, Adli Tıp Polikliniğine eşinden/partnerinden şiddet görme nedeniyle adli rapor düzenlenmesi için başvuran olguların demografik verileri yanı sıra, son bir yıl içindeki hastane başvuruları değerlendirilmiştir. Kadına yönelik aile içi şiddet nedeniyle, Adli Tıp Polikliniğine veya Acil Servise müracaat eden olgularla ilgili yapılan diğer çalışmalarda ise şiddetin türü ve ağırlığı gibi dinamiklere yer verilmiş, ancak aynı olguların şiddet dışı yakınmalarla hastane başvuruları değerlendirilmemiştir $(20,21)$.

Çalışmamızda, eş/partner şiddeti mağdurlarının, şiddet tarihinden önceki bir y1l içinde nedeni tam açıklanamayan, bedenselleştirme olarak değerlendirilebilecek sağlık yakınmaları ile sık hastane başvurularının olduğu saptanmıştır. Elde edilen sonuçlar, yöntemi farklı olsa da bu konuda yapılan diğer çalışmaları destekler niteliktedir. Bu çalışmada, anket ya da klinik görüşmelerle elde 
edilen sonuçların, gerçek şiddet mağdurlarında sınandığı söylenebilir.

Çalışmanın kısıtlılıkları: Eş/partner şiddeti yaşayan olguların, hastanemiz dışındaki başka sağlık kuruluşlarına olan başvuruları değerlendirilememiştir. Çalışma ayrıca, şiddet tarihinden önceki bir yıl içindeki hastane başvuruları ile sınırlı olup daha öncesi veya şiddet sonrası başvurularını içermemektedir.

\section{Sonuç}

Polikliniğimize eş/partner şiddeti nedeniyle başvuranların büyük çoğunluğu kadınlardır. Şiddet yaşayanlarin psikosomatik semptom ve yakınmalarla yıllık hastane başvuruları 10'un üzerinde olabilmektedir. Cinsiyet fark1 gözetmeksizin, eş şiddetine uğrayan kişilerin hastaneye başvuru semptomlarının yarısından fazlasının psikosomatik olduğu düşünülmüştür. Psikosomatik olduğu düşünülen nedenlerle başvurma oranı, kadınlarda erkeklere göre daha fazladır. 39 yaş ve altı olguların görece fazlalığ 1 ; şiddetin bedenselleştirilerek ifade edilmesi şeklinde yorumlanabilir. Kadınların şiddetin sonuçlarını bedenselleştirmeleri/somatize etmeleri bir yardım çığlığı olarak değerlendirilmeli, adli tıp ve psikiyatri uzmanlarının yanı sıra tüm hekimlerin bu yönde farkındalığ 1 arttırılmalı, bilgi ve beceri kazanmaları sağlanmalıdır. Eş/partner şiddetine karşı koruyucu ve önleyici çalışmalar, kadının ve toplum sağlığının geliştirilmesi yanı sıra gereksiz sağlık harcamalarının azaltılmasına da katkı sağlayacaktır.

\section{Kaynaklar}

1. İncecik Y, Kurdak H, Özcan S, Akpınar E, Saatçı E, Bozdemir N. Eş Şiddeti ve Aile Hekimliği. Turkish J Fam Med Primary Care. 2009;3(1):1-8.

2. Kandemir G, Ak İ. Tıbben Açılanamayan Belirtilerin Psikiyatrik Yönü. Psikiyatride Güncel Yaklaşımlar. 2013; 5(4):479-506.

3. Güleç H, Sayar K, Güleç MY ve ark. Bedensel Duyumları Abartma Ölçeği Türkçe Formunun Geçerlik ve Güvenirliği. Düşünen Adam: Psikiyatri ve Nörolojik Bilimler Dergisi. 2007; 20(1): 16-24.

4. Robbins JM, Kirmayer LJ. Attributions of common somatic symptoms. Psychol Med.1991; 21:1029-1045.

5. Özmen M. Bedenselleştiren hastaya yaklaşım. Klinik Gelişim Dergisi. 2009; 22(4): 34-38.

6. Özkorumak E, Güleç H, Kose S, Borckardt J, Sayar K. Depresyon hastalarında tıp dışı yardım arama davranışı: Aleksitimi bir etken olabilir mi? Klinik Psikiyatri Dergisi. 2006; 9:161-169.

7. Temiz M, Beştepe E, Yıldız Ö ve ark. The Effect of Violence on the Diagnoses and the Course of Illness Among Female Psychiatric Inpatients. DOI: 10.4274/npa.y6548. Arc Neuropsychiatry. 2014; 51: 1-10.
8. Vahip I, Doğanavşargil Ö. Aile İçi Fiziksel Şiddet ve Kadın Hastalarımız. Türk Psikiyatri Dergisi. 2006; 17(2):107-114.

9. Kayahan B, Altıntoprak E, Karabilgin S, Öztürk Ö. On beşkırk dokuz yaşları arasındaki kadınlarda depresyon prevalansı ve depresyon şiddeti ile risk faktörleri arasındaki ilişki. Anatolian J Psychiatry. 2003; 4:208-219.

10. Güleç H, Sayar K, Özkorumak E. Depresyonda Bedensel Belirtiler. Türk Psikiyatri Dergisi. 2005; 16(2):90-96.

11. Özer Ü, Selimoğlu E, Badur E ve ark. Fibromiyalji olgularında aile içi fiziksel şiddetin ağrı şiddeti, depresyon ve anksiyete düzeyleri ile ilişskisi. Nobel Medicus. 31. 2015; 11(1): 27-32.

12. Çilli AS, Kaya N, Bodur S ve ark. Ev kadınlarında ve çal1şan evli kadınlarda psikolojik belirtilerin karşılaştırılması. Genel Tip Dergisi. 2004;14(1):1-5.

13. Coker AL, Davis E, Arias I, Desai S et al. Physical and mental health effects of intimate partner violence for men and women. Am J Preventive Med. 2002;23(4):260-68.

14. Coker AL, Smith PH, Bethea L et al. Physical Health Consequences of Physical and Psychological Intimate Partner Violence. Arch Fam Med. 2000;9:451-457.

15. Doğanavşargil Ö, Vahip I. Fiziksel Eş Şiddetini Belirlemede Klinik Görüşme Yöntemi. Klinik Psikiyatri. 2007;10:125-136.

16. Elisberg M, Jansen H, Heise I et al. Intimate partner violence and women's physical and mental health in the WHO multi-country study on women's health and domestic violence: an observational study. The Lancet. 2008; 317: 1165-1172.

17. Breiding MJ, Black MC, Ryan GW et al. Chronic Disease and Health Risk Behaviors Associated with Intimate Partner Violence-18 U.S. States/Territories, 2005. Ann Epidemiology. 2008; 18(7):538-44.

18. Aile ve Sosyal Politikalar Bakanlığı, Kadının Statüsü Genel Müdürlüğü ve Hacettepe Üniversitesi. Türkiye'de Kadına Yönelik Aile İçi Şiddet Araştırması, Özet Rapor. Aralık 2014, Ankara.

19. Demirçin S. Kadına Yönelik Fiziksel Şiddet Olgularının Klinik Adli Tıbbi Değerlendirilmesi ve Yönetilmesi, Türkiye Klinikleri J Foren Med-Special Topics. 2016;2(2):56-61.

20. Yavuz SM, Aşırdizer M. Celal Bayar Üniversitesi Tıp Fakültesi Adli Tıp Polikliniğine Başvuran Aile İçi Şiddete Maruz Kalmış Kadın Olguların Analizi. Adli Tıp Dergisi. 2009; 23(1): 15-23

21. K1lıççığlu DB, Buran CF, Küçük ZS. Acil servise başvuran kadına yönelik şiddet olgularına adli tıbbi bakış: İzmir örneği. J Human Sci. 2016; 13(3): 4764-4779.

22. Özyurt BC, Deveci A. Manisa'da Kırsal Bir Bölgedeki 1549 Yaş Evli Kadınlarda Depresif Belirti Yaygınlığı ve Aile İçi Şiddetle İlişkisi. Türk Psikiyatri Dergisi 2010;21: 1-7.

23. Pico-Alfonso MA, Linares IG, Nawarm NC et al. The Impact of Physical, Psychological, and Sexual Intimate Male Partner Violence on Women's Mental Health: Depressive Symptoms, Posttraumatic Stress Disorder, State Anxiety, and Suicide. J Women's Health. 2006, 15(5): 599-611.

24. Köse A, Beşer A. Kadının Değiştirilebilir Yazgısı "Şiddet". Atatürk Üni. Hemşirelik Yüksekokulu Dergisi, 2007; 10 (4): 114-121. 